that tropical medicine is merely a facet of general medicine and that disease recognizes neither colour nor race. Geographical factors undoubtedly play a part, but, fundamentally, the sick African and the sick Asian respond to the vicissitudes of life in the same way as the sick Caucasian. Equally important in emphasizing the universality of disease, from the British practitioner's point of view, has been the increasing number of African, Asian and West Indian immigrants settling in Britain, and to-day practitioners are encountering diseases entirely new to them. It is mainly for these reasons that a symposium in The Practitioner has been devoted to "Tropical Medicine" (193, No. 1154; August 1964). The symposium presents an authoritative review of the more important aspects of the subject. As modern methods of transport speed up the comings and goings of the inhabitants of all five continents, it is incumbent on every practitioner to be aware of this world picture of medicine.

\section{Training Courses in Concrete}

THE programme of residential training courses offered by the Cement and Concrete Association in 1965 varies little from that of the previous year (Training Courses in Concrete-Prospectus and Programme for 1965. Pp. 15. London : Cement and Concrete Association, 1964). The Prospectus and Programme for 1965 now available lists the various courses offered at different times spread throughout the year; it includes instruction on many aspects of concrete technology, among which may be mentioned: concrete roads and cement-stabilized bases for general foremen, clerks of works and highway superintendents; concrete for engineers; concrete mix design and quality control for engineers; ultimate load design; design of reinforced and pre-stressed concrete bridge decks (in two parts, including a combined course and overseas visit); concrete roads and cement-stabilized bases for engineers; concrete construction for local government engineers and surveyors; formwork for engineers; concrete for architects; concrete products: concrete technology for suppliers of ready-mixed concrete; and aggregates for concrete. The educational and technical value of these training courses, ever since their inception, has been widely appreciated, as is attested by the fact that the demand for places offered during 1964 was such that as many applications had to be refused as were accepted. This is one of the reasons why the programme for 1965 is following closely the 1964 pattern: to give those who could not be admitted in 1964 an opportunity to attend in 1965 . With an eye to the future, the decision has boen made to build a new Training Centre on a neighbouring estate recently acquired by the Association, capable of housing more than twice the number of applicants at present catered for. It is anticipated that tho new premises, on which work has already begun, will be ready for use in 1966. As a result of this move, the residential facilities at the Centre will be greatly improved; two fully equipped lecture theatres and now laboratories will be built, with greatly increased facilitics for carrying out the experimental work which is a vital part of most of the courses.

\section{Crystallographic Course in Peking}

A schoor in "Experimental X-ray Crystallography" was hold, under the auspices of the Scientific and Technical Association of the Peoples' Republic of China, in the recently built Conference House, Peking, during November $: 14$. About 70 students attended the lectures and demonstrations and a further 60 attended the lectures only. The course was similar to that held in Cambridge during August 31-September 2 (Nature, 204, 731; 1964). The lectures, originally written in Fnglish by Dr. W. A. Wooster, had been translated and were delivered in Chinese by members of the staffs of various universities and academic institutes. The translated lectures wore printed together with all diagrams, photographs and charts, and a complete set of this material was issued to each student before the course began. The lecturers amplified the original text, where they thought it would help the students, and the style of lecturing showed a good understanding of the students' needs. In the practical demon. strations, Dr. Nora Wooster and Mr. A. M. Wooster assisted, and, with the aid of interpreters, the language difficulty did not prove serious. The students came not only from Peking but also from distant parts of China. In addition to the 20 lectures and demonstrations there were seven sessions of questions put by the students- the day's work started at 8 a.m. and continued through to 6 p.m. The large Conference House, Peking, was completed in four months during this surnmer. It had a well-equipped lecture theatre, and numerous rooms were made available for the practical demonstrations. Apparatus for demonstration in the lectures was lent by many institutes, and the willing co-operation shown by so many professors and research workers was the basis of the successful organization of the course, under Prof. Wu Chien-chang (Institute of Physics, Peking).

\section{The Jean Julliard Hæmostasis Prize}

AN annual prize of 2,000 French franes is being offered by the Editor of the journal Hémostase in memory of one of its foundors, the late Jean Julliard. The prize is intended to honour and to assist a young research worker who submits an original paper on an experimental or clinical subject relating to hæmostasis, coagulation, hæmorrhagic disease or thrombosis. In exceptional cases the award may be shared. Candidates, who may be of any nationality, must be less than 35 years old. Manuscripts may be written in French or English and the prizewinning entry will be published in the journal. Further information can be obtained from Editions S.P.F.I., Département Médical, 14, rue Drouot, Paris-9ème.

\section{Announcements}

Dr. Romert Glen, assistant deputy minister (research) of the Canada Department of Agriculture, has been awarded the 1964 Gold Medal of the Entomological Society of Canada, in recognition of his distinguished services to entomology, especially his outstanding research on elaterid larvæ.

THE Scientific Products Foundation Award for "Outstanding Contribution to the Advancement of Pathology" for 1964 has been conferred on Dr. Alan R. Moritz, vice-president of Western Resorve University, for his many contributions to the field of forensic pathology. Dr. Morit\% was instrumental in founding the first academic department of forensic medicine in the United States, at Hurvard University. The award is made by the College of American Pathology.

A symposium on "Modern Aspects of Stereochemistry", arranged by the Sheffield Local Section of the Chemical Society, will be held in Sheffield on December 18. Further information can be obtained from Dr. J. McKenna, Department of Chemistry, The University, Sheffield.

AN informal open meeting on "Electronic States of Biological Macromolecules" will be held by the Physical Biochemistry Group of the British Biophysical Society at King's College, London, on January 16. Further information can be obtained from Dr. A. Herzenberg, Department of Theoretical Physies, University of Manchester.

Conrigendum. In the article "European Mid-Devonian Correlations", which appeared on p. 363 of the October 24 issue of Nature, the words "half-size" in the caption to Fig. 1 should read "twice natural size", and "Desatrypta fiabellata" should read "Desalrypa flabellata". In the caption to Fig. 2, "half-size" should read "natural size". 